\title{
Unraveling the structure and composition of Varadero Reef, an improbable and imperiled coral reef in the Colombian Caribbean
}

Valeria Pizarro ${ }^{\text {Corresp., }}{ }^{1}$, Sara C Rodríguez ${ }^{2}$, Mateo López-Victoria ${ }^{2}$, Fernando A Zapata ${ }^{3}$, Sven Zea ${ }^{4}$, Claudia T Galindo-Martínez ${ }^{5}$, Roberto Iglesias-Prieto ${ }^{5}$, Joseph Pollock ${ }^{5}$, Mónica Medina ${ }^{5}$

1 Ecomares NGO, Cali, Valle, Colombia

2 Department of Natural Sciences and Mathematics, Pontifica Universidad Javeriana, Cali, Valle, Colombia

3 Department of Biology, Universidad del Valle, Cali, Valle, Colombia

${ }^{4}$ Centro de Estudios en Ciencias del Mar - CECIMAR, Universidad Nacional de Colombia - Sede Caribe, Santa Marta, Magdalena, Colombia

${ }^{5}$ Department of Biology, Pennsylvania State University, State College, Pennsylvania, United States

Corresponding Author: Valeria Pizarro

Email address: valeria.pizarro@ecomares.org

Coral reefs are commonly associated with oligotrophic, well illuminated waters. In 2013, a healthy coral reef was discovered in one of the least expected places within the Colombian Caribbean: at the entrance of Cartagena Bay, a highly-polluted system that receives industrial and sewage waste, as well as high sediment and freshwater loads from an outlet of the Magdalena River (the longest and most populated river basin in Colombia). Here we provide the first characterization of Varadero Reef's geomorphology and biological diversity. We also compare these characteristics with those of a nearby reference reef, Barú Reef, located in an area much less influenced by the described polluted system. Below the murky waters, we found high coral cover of $45.1 \%$ ( \pm 3.9 ; up to $80 \%$ in some sectors), high species diversity, including 42 species of scleractinian coral, 38 of sponge, three of lobster, and eight of sea urchin; a fish community composed of 61 species belonging to 24 families, and the typical zonation of a Caribbean fringing reef. All attributes found correspond to a reef that, according to current standards should be considered in "good condition". Current plans to dredge part of Varadero threaten the survival of this reef. There is, therefore, an urgent need to describe the location and characteristics of Varadero as a first step towards gaining acknowledgement of its existence and garnering inherent legal and environmental protections. 


\section{Unraveling the structure and composition of Varadero Reef, \\ 2 an improbable and imperiled coral reef in the Colombian \\ 3 Caribbean}

5 Valeria Pizarro ${ }^{1}$, Sara C. Rodríguez ${ }^{2}$, Mateo López-Victoria ${ }^{2}$, Fernando A. Zapata ${ }^{3}$, Sven Zea ${ }^{4}$,

6 Claudia T. Galindo-Martínez ${ }^{5}$, Roberto Iglesias-Prieto ${ }^{5}$, Joseph Pollock ${ }^{5}$, Mónica Medina ${ }^{5}$

$7 \quad{ }^{1}$ Ecomares NGO, Cali, Valle, Colombia

$8 \quad 2$ Department of Natural Sciences and Mathematics, Pontificia Universidad

9 Javeriana, Cali, Valle, Colombia

$10{ }^{3}$ Department of Biology, Universidad del Valle, Cali, Valle, Colombia

$11{ }^{4}$ Centro de Estudios en Ciencias del Mar - CECIMAR, Universidad Nacional de Colombia,

12 Santa Marta, Magdalena, Colombia, sezeas@unal.edu.co

$13{ }^{5}$ Department of Biology, Pennsylvania State University, State College, Pennsylvania, United

14 States

15 Corresponding Author:

16 Valeria Pizarro ${ }^{1}$

17

18 Calle 5B \# 4-139, Santa Marta, Magdalena, Colombia

19

Email address: valeria.pizarro@ecomares.org 


\section{Abstract}

22 Coral reefs are commonly associated with oligotrophic, well illuminated waters. In 2013, a healthy coral reef was discovered in one of the least expected places within the Colombian Caribbean: at the entrance of Cartagena Bay, a highly-polluted system that receives industrial and sewage waste, as well as high sediment and freshwater loads from an outlet of the Magdalena River (the longest and most populated river basin in Colombia). Here we provide the first characterization of Varadero Reef's geomorphology and biological diversity. We also compare these characteristics with those of a nearby reference reef, Barú Reef, located in an area much less influenced by the described polluted system. Below the murky waters, we found high coral cover of $45.1 \%$ ( \pm 3.9 ; up to $80 \%$ in some sectors), high species diversity, including 42 species of scleractinian coral, 38 of sponge, three of lobster, and eight of sea urchin; a fish community composed of 61 species belonging to 24 families, and the typical zonation of a Caribbean fringing reef. All attributes found correspond to a reef that, according to current standards should be considered in "good condition".

Current plans to dredge part of Varadero threaten the survival of this reef. There is, therefore, an urgent need to describe the location and characteristics of Varadero as a first step towards gaining acknowledgement of its existence and garnering inherent legal and environmental protections.

\section{Introduction}

Coral reefs provide important ecosystem services (Moberg \& Folke, 1999), but many currently face unprecedented pressure from multiple natural and anthropogenic stressors (Wilkinson, 2008). Caribbean reefs have been particularly impacted, with coral cover decreasing from an average of $50 \%$ to $10 \%$ in just four decades (Jackson et al., 2014). Coral cover loss has resulted in a phase shift from coral to macroalgal domination with a concurrent increase in sponge abundance (e.g., Rose and Risk, 1985; Szmant, 2002; Ward-Paige et al., 2005; Chaves-Fonnegra et al., 2007; Maliao et al., 2008; Jackson et al., 2014).

Coral reef ecosystems, built mainly by scleractinian corals, typically thrive within a narrow range between 33 and 36 psu (Kleypas, McManus \& Meñez, 1999; Díaz et al., 2000; Sheppard, Davy \& Pilling, 2009). Although reefs can be found outside these ranges in "extreme" environmental 
50 conditions, such reefs are typically dominated by a low number of resistant specialist species.

51 Some examples include reefs under higher water temperatures in the Persian Gulf and Hawaii 52 (Oliver \& Palumbi, 2009; Riegl \& Purkis, 2012), reefs under low pH waters in Japan and Papua 53 New Guinea (Fabricius et al., 2011; Inoue et al., 2013), and reefs under high salinity such as those 54 at the Arabian Sea where salinity can exceed 45 psu and temperatures regularly top $34{ }^{\circ} \mathrm{C}$ (Rezai 55 et al., 2004).

In 2013, a reef was discovered under unexpected conditions below a thick layer of highly turbid water at the mouth of Cartagena Bay, Colombia (López-Victoria et al., 2015). This reef, known as Varadero, is located south of Tierra Bomba Island, at the mouth of the highly polluted Bay. The man-made "Canal del Dique" dumps industrial and sewage waste as well as discharges of sediment from the Magdalena River into the vicinity of Varadero. With a drainage basin covering 24\% of Colombia's surface area (27.3 million hectares), the Magdalena River feeds approximately $144 \mathrm{x}$ $10^{6}$ tons of suspended solids into Cartagena Bay each year. This enormous sediment load has contributed to the demise of the Bay's once vibrant coral reefs (Restrepo et al., 2006). Paradoxically, Varadero Reef has not only survived, but thrived with up to $80 \%$ coral cover dominated by large Orbicella spp. colonies, the major reef-building corals in the Caribbean (López-Victoria et al. 2015).

Despite its close proximity to the city of Cartagena, Colombia ( $>1$ million inhabitants), Varadero Reef remained concealed due to the perception that local environmental conditions were incompatible with reef growth. High levels of sedimentation and turbidity have previously been shown to drive coral bleaching and disease that can ultimately lead to coral death (Bruno et al., 2003; Harvell et al., 2007; Pollock et al., 2014). Here we provide a preliminary characterization of Varadero Reef, including its geomorphology (i.e., size, shape and location) and biological diversity (i.e., coral, fish and sponge community composition). We also compare these characteristics with those of a nearby reference reef, Barú Reef, located $4.5 \mathrm{~km}$ south of Varadero, in a location much less influenced by runoff from the Canal del Dique and the city of Cartagena.

Current plans to dredge part of Varadero threaten the survival of this reef and could hinder researchers' ability to gain insights into the factors that have allowed corals to thrive under such unusual conditions. There is, therefore, an urgent need to describe the location and characteristics 
79 of Varadero as a first step towards gaining acknowledgement of its existence and garnering

80 inherent legal and environmental protections.

\section{Materials \& Methods}

82 In order to supplement the brief, general description of Varadero Reef reported by López-Victoria 83 et al. (2015), detailed geomorphological and biological surveys were performed between 2014 84 (March) and 2015 (March and October). During the March 2015 field trip, the reef's geographic extent was assessed by two researchers diving along the reef edge with a GPS, recording in tracking mode, attached to an accompanying buoy. Data from the GPS was downloaded and analyzed using the GIS software Garmin BaseCamp, from which a detailed map of the reef was subsequently produced. The reef's coral diversity was characterized by two coral experts performing three replicate profiles starting in the deepest zone (in direction to open sea) towards Cartagena Bay (shallowest zone). These annotations, including coral community composition at multiple depths, were analyzed as in Geister (1977). All profiles were compared and compiled to obtain a detailed profile of the reef's coral community structure and diversity.

The vertical attenuation coefficients $\left(K_{d}\right)$ were determined at both sites using the cosine corrected sensor of a diving pulse modulated fluorometer (PAM) (Waltz, Germany). The PAM sensor was calibrated against a traceable reference sensor LiCor (USA). A diver operating the PAM maintained the instrument in a horizontal position and triggering the data collection system of the fluorometer at different depths. The maximum excitation pressure over photosystem II $\left(Q_{m}\right)$ was calculated in both sites using the effective quantum yield of photosystem II at apparent noon $\left(\Delta F / F m^{\prime}\right)$ and the maximum quantum yield of charge separation at dusk $(F v / F m)$ (Iglesias-Prieto et al., 2004).

A detailed benthic community assessment was also conducted to evaluate sessile and mobile species composition, fish diversity and abundance, and sponge richness. To allow comparison of Varadero with a nearby reef that reflected typical Caribbean reef environmental conditions, a reef on the Barú Peninsular (from now on Barú Reef) was also surveyed. At each reef, five stations were established and two 30-m transects were deployed in the same landscape unit (i.e., reef type and depth). Quadrats (50 by $50 \mathrm{~cm}$ ) were placed every three meters on each side of the transect

107 and photographed for a total of 20 photo quadrats per transect. Each photograph was analyzed 
108 using Coral Point Count 4.1 software (Kohler \& Gill, 2006), which randomly places 50 points 109 within the quadrat for a randomly stratified methodology (Kohler \& Gill, 2006; Dumas et al., 2009; 110 Andersen et al., 2012). The benthic component below each point was identified and categorized 111 as coral (identified to species level), sponge (identified to species level), algal overgrown dead 112 coral, sand/rubble or other invertebrates (e.g., tunicates, gorgonians or zoantharians). Mobile reef 113 invertebrates were also assessed using the same benthic transects. A visual census was preformed 114 of all sea urchins, conchs, and lobsters within a 1-m wide band of the transect. Macroalgal 115 communities were characterized by randomly selecting five photo quadrats per transect, randomly 116 placing 10 points within each quadrat (using Coral Point Count 4.1), and categorizing any observed 117 macroalgae as fleshy, coralline or turf. Fleshy algae were identified to genus level. To compare 118 Varadero and Barú Reefs, species richness, abundance and composition were tested for normal 119 distributions (Shapiro-Wilk's test) then compared using a two sample Student's t-test in the software PAST version 3.14 (Hammer, Harper, \& Ryan, 2001).

121 During exploratory dives, sponges were visually identified while swimming over the reef. 122 Photographs and small samples were also taken for downstream spicule examination in cases when 123 sponges could not be readily distinguished in the field. Species lists were made for both Varadero 124 and Barú Reefs, separately for the upper terrace (down to $10-13 \mathrm{~m}$ ) and slope (below $10-13 \mathrm{~m}$ ) 125 zones. Sponge species present within each of the $30 \times 2-\mathrm{m}^{2}$ band transects in the shallow terrace 126 zone of Varadero $(n=7$ transects) and Barú $(n=4$ transects) were also recorded. This sampling 127 scheme permitted calculation of gross abundances as percent frequency of occurrence (number of 128 transects in which a sponge was present/total transects) and species richness per transect. Data on 129 total coral and sponge cover obtained in 10 photo transects (covering $5 \mathrm{~m}^{2}$ each, see above) in the 130 upper terrace of each locality were also analyzed for trends in cover of sponges vs. corals vs. 131 available substratum using simple correlation analysis. For sponge identification in the laboratory, 132 small fragments of each collected sponge were digested in commercial bleach to obtain free 133 spicules, which were observed under a light microscope. Species were identified using specialized 134 literature and extensive local knowledge/experience (see Zea, 1987; Zea et al., 2014).

135 Overall fish diversity and community composition were visually assessed. In order to compile fish 136 species lists for each reef, a team of three divers recorded all fishes observed while exploring the 137 general reef areas of Varadero and Barú during a total of 8 dives on each reef (approximately 1- 
138 hour per dive), in 2014 and 2015. In 2015, 22 visual censuses were performed along 30x2-m² belt 139 transects ( $\mathrm{n}=15$ at Varadero and $\mathrm{n}=7$ at Barú) to characterize fish community composition. All 140 individuals observed within each belt transect were counted and these counts were used to estimate 141 mean species richness, diversity (Shannon's H'), dominance (Simpson's D) and evenness (Pielou's $142 \mathrm{~J}$ '). These community variables were compared between Varadero and Barú using a two sample

143 Student's t-test, after establishing that the data met assumptions of normality and homoscedasticity 144 with Shapiro-Wilk's and F tests, respectively. All tests were performed using PAST 3.14 145 (Hammer, Harper \& Ryan, 2001).

146 To assess species abundance differences between sites, a regression analysis of mean species 147 abundance was performed along with paired Student's t-tests. Given the different sampling efforts 148 between the two localities, a sample-based rarefaction procedure was carried out to compare fish

149 species richness between Varadero and Barú. Finally, a non-Metric Multidimensional Scaling 150 (nMDS) analysis was carried out using Jaccard's similarity index (based on species occurrence) 151 and the Bray-Curtis similarity index [based on the $\log (\mathrm{x}+1)$ transformed abundance data] to 152 examine differences in assemblage structure between the two localities based on species 153 composition and abundance, respectively. The nMDS analysis was complemented with analyses 154 of similarity (ANOSIM) based on either Jaccard or Bray-Curtis similarity. All statistical analyses 155 and calculation of community indices were performed using the software PAST 3.11 (Hammer, 156 Harper \& Ryan, 2001).

\section{Results}

$158 \quad$ Geomorphology and optical properties

159 Located between the Bocachica navigation channel and the island of Barú, Varadero Reef has an 160 area of approximately $1.12 \mathrm{~km}^{2}$ (Figure 1). The reef has two contrasting zones, the first $\left(0.44 \mathrm{~km}^{2}\right)$ 161 is a well-developed reef where scleractinian coral colonies dominate the substratum. The second $162\left(0.68 \mathrm{~km}^{2}\right)$ is a carbonated terrace with scattered corals, octocorals, a few other benthic species 163 and sand patches with seagrasses (Figure 1c, Figure 2). The largest seagrass beds were observed 164 near the islands of Draga and Abanico (Figure 1c). Analyses of the vertical attenuation coefficients 165 of the water in both sites indicate significant vertical stratification. We identify an upper layer with 166 high attenuation values located between the surface and 3-5 $\mathrm{m}$ depth. Comparisons between the 
167 attenuation coefficients of the first layer at both sampling sites indicate significantly $(\mathrm{p}<0.001$

168 ANOVA) higher attenuation values for Varadero Reef $\left(0.336 \pm 0.050 \mathrm{~m}^{-1}\right.$, average $\left.\pm \mathrm{SE}, \mathrm{n}=32\right)$

169 relative to Barú Reef $\left(0.243 \pm 0.053 \mathrm{~m}^{-1,} \mathrm{n}=11\right)$. In some cases, we identify a second layer with

$170 K_{d}$ values ranging between 0.193 and $0.051 \mathrm{~m}^{-1}$ at depths above the limit of the first layer between

171 three to five meters. (Figure 3). Depending on the depth profile of the reef, some corals were

172 completely contained within the first optical layer (Figures 2-3). We recorded the maximum

173 excitation pressure of photosystem II for Orbicella faveolata colonies growing in the shallow parts

174 of both reefs. In both cases corals were exposed to irradiances high enough to induce significant

175 levels of photoprotection at noon with Qm values of $0.208 \pm 0.109$, average $\pm \mathrm{SE}, \mathrm{n}=25$ at $4.5 \mathrm{~m}$

176 depth and $0.249 \pm 0.052, \mathrm{n}=25$ at $6.0 \mathrm{~m}$ depth for Varadero and Barú Reefs respectively.

\section{Coral and benthic community}

178 In total, 42 scleractinian coral and four hydrocoral species (Families Milleporidae and 179 Stylasteridae) were identified at Varadero (Supplemental Table 1). These species include several 180 threatened species such as the acroporids (Acropora cervicornis and A. palmata). Depth profiles 181 indicate that Varadero Reef's calcareous matrix starts at around 27 to $35 \mathrm{~m}$ depth (Figure 2). At 182 greater depths, moving towards open sea, the sand bottom has small patches of sponges and black 183 corals (Anthipatharia). Coral cover from 27 to $35 \mathrm{~m}$ until approximately 10 to $12 \mathrm{~m}$ is relatively 184 low (1 to 5\%) and the reef slope is around $45^{\circ}$. Coral communities at this depth range are dominated 185 by Agaricia spp. (A. lamarcki, A. grahamae), Madracis spp. and Helioseris cucullata. At $25 \mathrm{~m}$ 186 and shallower, small plate-like growth forms of Siderastrea siderea, Montastraea cavernosa and 187 Mycetophyllia aliciae were observed. Besides corals, tube and branching sponges, encrusting algae 188 and cyanobacteria are present. At $18 \mathrm{~m}$ and shallower, small patches of Agaricia tenuifolia start to 189 appear, becoming more abundant until they dominate the landscape between 12 and $10 \mathrm{~m}$. Between 19012 and $10 \mathrm{~m}$, live coral cover is $40-45 \%$, the slope decreases to $25-30^{\circ}$ and other scleractinian 191 species are present, including Colpophyllia natans, H. cucullata, Madracis auretenra, O. 192 faveolata, Porites astreoides, and Scolymia cubensis become more common. At 10 - $12 \mathrm{~m}$ depth, 193 growth morphologies of typically massive species are plate-like and small ( $\sim 10-40 \mathrm{~cm}$ maximum 194 diameter). Madracis auretenra also forms scattered monospecific patches in this area.

195 At approximately $8 \mathrm{~m}$ depth, the slope decreases to $10-15^{\circ}$, corals are more abundant and larger

196 (up to $2-3 \mathrm{~m}$ diameter), but the main coral matrix is still dominated by Agaricia tenuifolia and in 
197 some areas is mixed with Porites divaricata. The morphology of typically massive coral species

198 is a mix of massive and plate. The most common species are Meandrina meandrites, Montastraea 199 cavernosa, Mycetophyllia ferox, Orbicella annularis, O. faveolata, Pseudodiploria strigosa, and 200 Siderastrea siderea. At this depth, it is possible to find A. cervicornis. At $6 \mathrm{~m}$, coral cover increases 201 to 50-60\%, massive corals become dominant (especially Orbicella spp.), and patches of Agaricia 202 tenuifolia and Porites divaricata can be found in sand patches. Between 5 and 3 m, massive corals 203 dominate the reefscape, Orbicella annularis and $O$. faveolata colonies with diameters exceeding $2045 \mathrm{~m}$ are common and the slope decreases to almost $0^{\circ}$. Other common coral species include 205 Agaricia agaricites, A. tenuifolia, Colpophyllia natans, Millepora alcicornis, M. complanata, $M$.

206

207

208

209

210

211

212

213

214

215

216

217

218

219

220

221

222

223

224

225

226

227 striata, Mycetophyllia aliciae, Pseudodiploria strigosa, Porites astreoides, P. divaricata, Scolymia cubensis and Siderastrea siderea. Live coral cover is higher than $50 \%$ and colonies of Acropora cervicornis, A. palmata and A. prolifera are found scattered throughout the reef. This area of high coral cover which is dominated by large colonies of Orbicella spp. continues until around $3 \mathrm{~m}$. At this depth, coral colony size and abundance decreases. Common coral species, between 3 and $2 \mathrm{~m}$ depth include Agaricia fragilis, A. tenuifolia, Favia fragum, Orbicella faveolata, Pseudodiploria clivosa, P. strigosa, Porites astreoides, P. divaricata, Montastraea cavernosa, Siderastrea siderea, as well as the milleporids Millepora complanata and M. striata. Most of the massive coral species' growth morphologies change to crustose, and the reef slope is less than $10^{\circ}$. Calcareous terraces appear at $2 \mathrm{~m}$. In this area, dispersed corals (Pseudodiploria clivosa, Siderastrea radians and S. siderea), octocorals, and sand patches are common. Towards the Bay, close to the islands of Abanico and Draga, seagrasses (i.e., Thalassia testudinum and Halodule wrightii) are common.

Varadero Reef's benthos between 3 and $15 \mathrm{~m}$ is dominated by live coral $(45.1 \pm 3.9 \%)$ and algaeovergrown dead coral $(47.5 \pm 4.0 \%$; average $\pm \mathrm{SE})$. Sand and rubble $(4.6 \pm 0.6 \%)$, sponges $(0.7 \pm$ $0.1 \%)$ and other invertebrates (gorgonians, zoanthids, etc.) $(1.8 \pm 0.9 \%)$ were also observed. In total, 38 coral species (scleractinian and fire corals) were identified at this depth. The most abundant species are Orbicella faveolata (38.1\%), Agarcia agaricites (28.8\%), O. annularis (14.4\%) and A. tenuifolia (12.2\%) (Supplemental Table 1). Similar to Varadero, the most common benthic components at Barú Reef are algae-overgrown dead coral (56.9 $\pm 2.7 \%)$ and live coral $(38.1 \pm 3.2 \%)$. The other benthic categories assessed show low percentage cover of sand and rubble $(3.4 \pm 1.6 \%)$, sponges $(0.8 \pm 0.2 \%)$ and other invertebrates $(0.9 \pm 0.3 \%)$. In total, 35 coral species 
228 were identified, and, similar to Varadero, the most common were Orbicella faveolata (25.6\%), 229 Agaricia agaricites (11.3\%), O. annularis (10.4\%) and A. tenuifolia (4.5\%) (Supplemental Table $2301)$.

232 In total, at Varadero and Barú fifty sponge species were observed with 38 and 31 species at each 233 reef, respectively. Survey transects at upper shallow terraces (between 3 and $10 \mathrm{~m}$ depth) at 234 Varadero Reef showed higher sponge species richness (36 in total) than that of upper shallow 235 terraces in Baru Reef (25 in total) although the number of species per transect were not 236 significantly different (t-Student test, $\mathrm{p}=0.86$ ), $10.0 \pm 1.23$ species per transect (mean \pm 1 standard 237 error, $\mathrm{n}=7$ transects) for Varadero, and 10.5 \pm 2.36 for Barú ( $\mathrm{n}=4$ transects) (Supplemental Table 238 2). Eight species, arranged by abundance, were observed in greater than $50 \%$ of terrace transects 239 on both reefs, Mycale laevis, Niphates erecta, Ircinia felix, Monanchora arbuscula, Lissodendoryx 240 colombiensis, Haliclona wallentinae, Cliona laticavicola and Scopalina ruetzleri. None of these 241 common species were exclusive to either reef, and when reef-specific species were observed, they 242 were typically comprised of single occurrences. Visually, sponge abundance was similarly low in 243 both Varadero and Barú Reef terraces though there were sponge patches growing on dead coral. 244 Mean coral cover estimated from phototransects was slightly but not significantly higher in 245 Varadero than in Barú $(45.1 \pm 14.3 \%$ vs. $38.1 \pm 12.0 \%$ respectively, t-Student test, $\mathrm{p}=0.18, \mathrm{n}=10$

246 transects per site, Figure 4). Sponge cover was equally low and similar between the two localities $247(0.66 \pm 0.21 \%$ and $0.80 \pm 0.25 \%$ respectively, t-Student test, $\mathrm{p}=0.52)$. Moreover, correlations 248 between per-transect total coral and sponge cover, although negative as expected, were not 249 significant (Varadero, $\mathrm{r}=-0.42, \mathrm{p}=0.22$; Barú, $\mathrm{r}=-0.06, \mathrm{p}=0.86$ ). Mean sponge cover was also 250 not significantly correlated with the availability of dead coral substratum (covered with turf and 251 macroalgae, Varadero, $r=0.42, p=0.23$; Barú, $r=0.36, p=0.30)$, which was higher in Barú (56.9 $252 \pm 18.0 \%)$ than in Varadero $(51.4 \pm 16.3 \%)$.

\section{Fish community}

254 A total of 61 fish species from 24 families was observed at Varadero Reef compared to 44 species 255 from 22 families observed at Barú. While a total of 67 species were observed at both sites 256 combined, 38 species were common to both. Twenty four species were observed at Varadero only, 
257 while six species were observed exclusively at Barú. Overall, Jaccard's coefficient of similarity 258 considering the full fish species list of each site was 0.57 (Supplemental Table 3). The number of 259 species per family was similar between Varadero and Barú $(\mathrm{r}=0.90, \mathrm{p}<<0.001, \mathrm{n}=26$ families) 260 and at both sites damselfishes (Pomacentridae) were the most species rich (8 and 7 species at 261 Varadero and Barú, respectively), followed by wrasses (Labridae; 5 species at each site), groupers

262 (Serranidae; 5 and 4 species, respectively) and parrotfishes (Scaridae; 4 species at each site; 263 Supplemental Table 3).

264 Considering only data from visual censuses, a total of 834 individuals belonging to 36 species 265 were observed at Varadero, while only 519 individuals of 32 species were observed at Barú. 266 Correcting for differences in sampling effort, sample-based rarefaction indicated that, for the same 267 number of samples, species richness was slightly greater at Barú than at Varadero (Supplemental 268 Figure 1). Nonetheless, mean species richness within transects at Varadero did not differ 269 significantly from mean species richness at Barú (Table 1). Except for the total number of 270 individuals per transect, which was on average significantly greater at Barú than at Varadero, none

271 of the other community parameters (Simpson's Dominance D, Shannon's Diversity H', and 272 Pielou's Evenness J') differ significantly between Varadero and Barú ( $\mathrm{p}>0.05)$ (Table 1). Even 273 though there was a highly significant positive correlation between the abundance of species 274 common to both sites (considering only species observed in transects at both sites; $r=0.95, \mathrm{p}<<$ $2750.001, \mathrm{n}=26$ species), a paired Student's t-test indicated that mean abundance was significantly 276 greater at Barú than at Varadero (mean difference $=0.78, \mathrm{t}=-2.51, \mathrm{p}=0.019$ ).

277 Results of the nMDS analysis showed that there was a great deal of overlap in fish assemblage 278 structure between Varadero and Barú considering either species composition alone (based on 279 Jaccard's similarity; Figure 5a) or species abundance and composition (based on Bray Curtis's 280 similarity; Figure 5b). ANOSIMs based on these two similarity measures indicated that the fish 281 assemblage at Varadero did not differ significantly from that at Barú (Jaccard-based ANOSIM, R $282=0.03, \mathrm{p}=0.37$; Bray-Curtis-based ANOSIM, $\mathrm{R}=-0.06, \mathrm{p}=0.69$ ).

\section{Discussion}

284 Caribbean coral reefs are declining rapidly due to anthropogenic activities (e.g., overfishing, 285 pollution, etc.), climate change and the synergies between these factors. Caribbean reefs have 
286 experienced declines in coral cover (and increases in macroalgae, cyanobacterial mats and sponge 287 cover), and reduction in the abundances of sea turtles, sharks and fish populations since the 1970s 288 (de Bakker et al., 2017; Jackson et al., 2014). Reef deterioration has not been equal throughout the 289 Caribbean with few regions still holding coral cover higher than 30\% (Gardner et al., 2003). Most 290 areas with relatively high coral cover are under some conservation/management program and have 291 experienced little anthropogenic influence from land-based pollution and fisheries (Jackson et al., 292 2014). Moreover, regional and global risk assessments correlate reefs' vulnerability to their 293 proximity to man-made stressors (Burke et al., 2011). The discovery of an apparently healthy reef 294 in Varadero adjacent to the major population center of Cartagena, Colombia, apparently runs 295 counter to the prevailing dogma. In addition, this reef is under the influence of the Magdalena 296 River Delta (Canal del Dique), considered as the biogeographical barrier for shallow and 297 mesophotic coral reefs ( $<200 \mathrm{~m}$ depth), limiting the dispersion of coral larvae (Santodomingo et 298 al., 2013).

299 The development of coral reefs under "sub-optimal" conditions (e.g., high sedimentation, 300 nutrients) does not appear to be a widespread phenomenon, though a few disparate cases have been 301 recently reported. These anomalous reef ecosystems can be found in warm waters (Liddell \& 302 Ohlhorst, 1987; Spalding \& Brown, 2015), upwelling-influenced areas (Bayraktarov et al., 2013), 303 high latitudes (Harriot \& Banks, 2002) and naturally turbid waters (Anthony, 2006; Smithers \& 304 Larcombe, 2003). Under extreme conditions, corals have adapted and/or acclimatized to the high 305 temperature variance, and heterotrophic feeding is their dominant feeding mode (Teece, et al., 306 2011; Hughes \& Grottoli, 2013). Most of the reefs subjected to ongoing or temporal sedimentation 307 have growth constrains due to the limitation on light penetration. Perry and Larcombe (2003) 308 predicted that reef framework development in turbid environments might be restricted or absent, 309 limiting coral distribution to shallow waters. Correspondingly, the portions of Varadero Reef with 310 highest coral cover are currently constrained to the shallower portions of the reef, were they appear 311 to be autotrophic as indicated by their relatively high $Q_{m}$ values. Environmental conditions at 312 Varadero Reef have changed drastically since the Spaniards arrived several centuries ago. As

313 described by Restrepo et al. (2017), before the opening of the Canal del Dique during the $16^{\text {th }}$ 314 century in the colonial period, and subsequent modifications in the $19^{\text {th }}$ Century, Cartagena Bay 315 had no river inputs and coral reefs and seagrass beds flourished inside the Bay (Martínez et al., 316 2010). The massive arrival of waters from the Magdalena River via the Canal del Dique, after the 
317 three major modifications to the channel in 1925, 1951 and 1984 (Mogollon, 2013), drastically

318 changed conditions within the Bay from clear, warm-waters to a tidal estuarine environment

319 (Restrepo et al., 2017). The dispersion patterns of the turbid plume of the Canal del Dique in the

320 Cartagena Bay are highly variable depending on the hydrodynamic and meteorological conditions

321 (Lonin et al., 2004). In this context, the optical properties of the water at Varadero Reef could 322 experiment dramatic short-term changes depending on the prevailing hydro-meteorological 323 conditions. The description of the variability in the optical properties of the water column is key 324 to understand the energy and calcification balance of the coral community.

325 Varadero Reef is highly influenced by local stressors including eutrophication, agro-chemical 326 runoff, port and industry development, and tourism activities. The main stressor being land-based 327 pollution that flows into the Bay through the Canal del Dique (Mogollón, 2013). In addition to the 328 influx of large volumes of fresh water, sediment loads arriving into the Bay can top 150 million 329 tons per year (Restrepo et al., 2006). Varadero Reef appears to be a relic of the reef formations 330 that dominated Cartagena Bay and adjacent coastal regions during the pre-Columbian period. 331 Despite these challenging environmental conditions, our results on reef structure and species 332 composition demonstrate that Varadero Reef is a functional ecosystem, fully developed and similar 333 to those found on nearby reefs (e.g., Barú and Rosario Archipelago) and Caribbean reefs more 334 broadly (Zea, 2001; Claro \& Cantelar-Ramos, 2003; Pattengill-Semmens \& Semmens, 2003; 335 Valderrama \& Zea, 2003; Alvarado-Chacon, Pizarro, \& Sarmiento-Segura, 2011; Kramer, Marks, $336 \&$ Turnbull, 2014).

337 The existence of Varadero, a "paradoxical reef" (López-Victoria et al., 2015), is a call for scientists 338 and managers to start looking in unexpected places for similar coral reefs or carbonate reef systems 339 as the one found at the Amazon River mouth (Moura et al., 2016). More importantly, Varadero 340 may hold information on reef coral resistance, and adaptations to high sedimentation and turbidity.

341 In this context, Varadero could serve as a natural laboratory and potentially provide source material 342 for reseeding future reef environments. Current reef degradation challenges the initial goal of 343 restoration ecology, meaning that returning to a pre-disturbance state might not be possible and/or 344 practical under present climate change (van Oppen et al., 2017). Tolerance to warmer and acidified 345 waters, greater fluctuations in salinity and exposure to nutrients, herbicides and other pollutants 
346 are critical coral resilience traits. Our observations and preliminary results of ongoing research

347 indicate that some of these traits can be found at Varadero, but further research is needed.

348 If the dredging for a new shipping channel is authorized by government authorities (Agencia

349 Nacional de Licencias Ambientales - ANLA), we estimate that $25 \%$ of the reef will be directly

350 affected and around $50 \%$ will be indirectly affected. The environmental impacts of this dredging

351 include sediment stress (suspended and deposited), release of toxic contaminants, noise

352 contamination, and complete destruction of benthic organisms within the dredge path (Rogers,

353 1990; Erftemeijer et al., 2012; Roberts, 2012). Depending on the intensity, duration and frequency

354 of increased turbidity and sedimentation, the impacts on corals may include: smothering and burial,

355 shading, bleaching, disease (Pollock et al. 2014), and decreased survival and recruitment success

356 of coral larvae (Erftemeijer et al., 2012). Additionally, a recent review on the effect of dredging

357 on fish suggests the potential for elevated fish mortality, especially in early life stages (eggs and

358 larvae) (Wegner et al, 2017). The destruction of Varadero Reef would be a loss for the scientific

359 community, for local stakeholders and for Colombia as a nation.

360

361

362

363

364

365

366

367

368

369

370

371

372

373

374

375

376

377

\section{Acknowledgements}

We would like to thank the community of Bocachica, specially the Eight Brothers with whom we did all our fieldwork in Varadero and Barú. This community has welcomed and teach us about their uses of Varadero Reef and other nearby areas. Additionally, to all the people including the crew of Oregon State University from Terra, that have spread the word about Varadero Reef.

\section{References}

Alvarado-Chacon EM, Pizarro V, Sarmiento-Segura A. 2011. Formaciones arrecifales. In ZarzaGonzalez E. ed. El entorno ambiental del Parque Nacional Natural Corales del Rosario y de San Bernardo. Cartagena de Indias: Parques Nacionales Naturales de Colombia, 109-123.

Andersen PK, Borgan O, Gill RD, Keiding N. 2012. Statistical models based on counting processes. New York: Springer Science \& Business Media.

Anthony KRN. 2006. Enhanced energy status of corals on coastal high-turbidity reefs. Marine Ecology Progress Series 319:111-116.

Bayraktarov E, Pizarro V, Eidens C, Wilke T, Wild C. 2013. Bleaching susceptibility and recovery of Colombian Caribbean corals in response to water current exposure and seasonal upwelling. PLoS ONE 8: e80536 DOI:10.1371/journal.pone.0080536.

Bruno JF, Petes LE, Drew Harvell CD, Hettinger A. 2003. Nutrient enrichment can increase the severity of coral diseases. Ecology letters 6:1056-1061. 
378

379

380

381

382

383

384

385

386

387

388

389

390

391

392

393

394

395

396

397

398

399

400

401

402

403

404

405

406

407

408

409

410

411

412

413

414

415

416

417

418

419

420

421

422

423

Burke L, Reytar K, Spalding M, Perry A. 2011. Reefs at risk revisited. Washington D.C.: World Resources Institute.

Chavez-Fonnegra A, Zea S, Gomez ML. 2007. Abundance of the excavating sponge Cliona delitrix in relation to sewage discharge at San Andrés Island, SW Caribbean, Colombia. Boletín de Investigaciones Marinas y Costeras 36:63-78.

Claro R, Cantelar-Ramos K. 2003. Rapid assessment of coral communities of María la Gorda Southeast Ensenada de Corrientes, Cupa (part 2: fishes). Atoll Research Bulletin 496:278-293.

de Bakker DM, van Duyl FC, Bak RPM, Nugues MM, Nieuwland G, Meesters EH. 2017. 40 years of benthic community change on the Caribbean reefs of Curaçao and Bonaire: the rise of slimy cyanobacterial mats. Coral Reefs 36:355-367.

Díaz JM, Barrios LM, Cendales MH, Garzon-Ferreira J, Geister J, Lopez-Victoria M, Ospina GH, Parra-Velandia F, Pinzón J, Vargas-Angel B, Zapata FA, Zea, S. 2000. Áreas coralinas de Colombia. Santa Marta: Serie Publicaciones Especiales No. 5.

Dumas P, Bertaud A, Peignon C, Leopold M, Pelletier D. 2009. A “quick and clean" photographic method for the description of coral reef habitats. Journal of Experimental Marine Biology and Ecology 368:161-168.

Erftemeijer PLA, Riegl B, Hoeksema BW, Todd PA. 2012. Environmental impacts of dredging and other sediment disturbances on corals: A review. Marine Pollution Bulletin 64:1737-1765.

Fabricius KE, Langdon C, Uthicke S, Humphrey C, Noonan S, De'ath G, Okazaki R, Muehllehner N, Glas MS, Lough JM. 2011. Losers and winners in coral reefs acclimatized to elevated carbon dioxide concentrations. Nature Climate Change 1:165-169.

Gardner TA, Cote IM, Gill JA, Grant A, Watkinson AR. 2003. Long-term region-wide declines in Caribbean corals. Science 301:958-960.

Geister J. 1977. The influence of wave exposure on the ecological zonation of Caribbean coral reefs. Proceedings of the 3rd International Coral Reef Symposium 1:23-29.

Hammer O, Harper DAT, Ryan PD. 2001. PAST: Paleontological Statistics Software Package for Education and Data Analysis. Palaeontolia Electronica 4:1-9.

Harriot V, Banks S. 2002. Latitudinal variation in coral communities in eastern Australia: a qualitative biophysical model of factors regulating coral reefs. Coral Reefs 21: 83-94.

Harvell D, Jordán-Dahlgren E, Merkel S, Rosenberg E, Raymundo L, Smith G, Weil E, Willis, B. 2007. Coral disease, environmental drivers, and the balance between coral and microbial associates. Oceanography 20:172-195.

Hughes AD, Grottoli AG. 2013. Heterotrophic compensation: a possible mechanism for resilience of coral reefs to global warming or a sign of prolonged stress? PLOS ONE 8:e81172.

Iglesias-Prieto R, Beltrán VH, LaJeunesse TC, Reyes-Bonilla H, Thomé PE. 2004. Different algal symbionts explain the vertical distribution of dominant reef corals in the eastern Pacific. Proceedings of the Royal Society of London B: Biological Sciences 271:1757-1763.

Inoue S, Kayanne H, Yamamoto S, Kurihara H. 2013. Spatial community shift from hard to soft corals in acidified water. Nature Climate Change 3:638-687.

Jackson J, Donovan M, Cramer K, Lam W. 2014. Status and trends of Caribbean coral reefs: 1970-2012. Gland, Switzerland: Global Coral Reef Monitoring Network, IUCN.

Kleypas JA, McManus JW, Meñez LAB. 1999. Environmental limits to coral reef development: where do we draw the line? American Zoologist 39:146-159.

Kohler KE. Gill SM. 2006. Coral Point Count with Excel extensions (CPCe): a visual basic program for the determination of coral and substrate coverage using random point count methodology. Computers \& Geosciences 32:1259-1269. 
424 Kramer PA, Marks KW, Turnbull TL. 2014. Assessment of Andros Island reef system, Bahamas

425

426

427

428

429

430

431

432

433

434

435

436

437

438

439

440

441

442

443

444

445

446

447

448

449

450

451

452

453

454

455

456

457

458

459

460

461

462

463

464

465

466

467

468

(part 2: fishes). Atoll Research Bulletin 496:100-123.

Liddell WD, Ohlhorst SL. 1987. Patterns of reef community structure, North Jamaica. Bulletin of Marine Science, 40: 311-329.

Lonin S, Parra C, Andrade C, Thomas Y.-F. 2004. Patrones de la pluma turbia del Canal del Dique en la Bahía de Cartagena. Boletín Científico CIOH 22:77-89

López-Victoria M, Rodríguez-Moreno M, Zapata FA. 2015. A paradoxical reef from Varadero, Cartagena Bay, Colombia. Coral Reefs 34:231.

Malaio R, Turingan R, Lin J. 2008. Phase-shift in coral reef communities in the Florida Keys National Marine Sanctuary (FKMNS), USA. Marine Biology 154:841-853.

Martínez JI, Yokoyama Y, Delgado A, Matsuzaki H, Rendon E. 2010. Late Holocene marine terraces of the Cartagena region, southern Caribbean: the product of neotectonism or a former high stand in sea-level? Journal of South American Earth Sciences 29:214-224.

Moberg F, Folke C. 1999. Ecological goods and services of coral reef ecosystems. Ecological Economics 29:215-233.

Mogollón JV. 2013. El Canal del Dique: historia de un desastre ambiental. Bogotá: El Áncora Editores.

Moura RL, Amado-Filho GM, Moraes FC, Brasileiro PS, Salomon PS, Mahiques MM, Bastos AC, Almeida MG, Silva JM Jr, Araujo BF, Brito FP, Rangel TP, Oliveira BCV, Bahia RG, Paranhos RP, Dias RJS, Siegle E, Figueiredo AG Jr, Pereira RC, Leal CV, Hajdu E, Asp NE, Gregoracci GB, Neumann-Leitão S, Yager PL, Francini-Filho RB, Fróes A, Campeão M, Silva BS, Moreira APB, Oliveira L, Soares AC, Araujo L, Oliveira NL, Teixeira JB, Valle RAB, Thompson CC, Rezende CE, Thompson FL. 2016. An extensive reef system at the Amazon River mouth. Science Advances 2:e1501252.

Pattengill-Semmens C, Semmens B. 2003. Status of coral reefs of Little Cayman and Grand Cayman, British West Indies, in 1999 (part 2: fishes). Atoll Research Bulletin 496:226-247.

Perry CT, Larcombe P. 2003. Marginal and non-reef-building coral environments. Coral Reefs 22:427-432.

Pollock FJ, Lamb JB, Field SN, Heron SF, Schaffelke B, Shedrawi G, Bourne DG, Willis BL. 2014. Sediment and turbidity associated with offshore dredging increase coral disease prevalence on nearby reefs. PLoS ONE 11: e0165541.

Restrepo JC, Escobar J, Otero L, Franco D, Pierini J, Correa I. 2017. Factors influencing the distribution and characteristics of surface sediment in the Bay of Cartagena, Colombia. Journal of Coastal Research 331:135-148.

Restrepo JD, Zapata P, Díaz JM, Garzón-Ferreira J, García CB. 2006. Fluvial fluxes into the Caribbean Sea and their impact on coastal ecosystems: the Magdalena River, Colombia. Global and Planetary Change 50: 33-49.

Rezai H, Wilson S, Claereboudt M, Riegl B. 2004. Coral reef status in ROPME Sea area. In Wilkinson C, ed. Status of coral reefs of the world. Townsville, Australia: Australian Institute of Marine Science, 155-170.

Riegl BL, Purkis SJ. 2012. Coral reefs of the Gulf: adaptation to climatic extremes in the world's hottest sea. In: Riegl BL \& Purkis SJ, eds. Coral reefs of the Gulf: adaptation to climatic extremes. USA: Springer Science \& Business, 1-4.

Roberts DA. 2012. Causes and ecological effects of resuspended contaminated sediments (RCS) in marine environments. Environment International 40:230-243. 
469

470

471

472

473

474

475

476

477

478

479

480

481

482

483

484

485

486

487

488

489

490

491

492

493

494

495

496

497

498

499

500

501

502

503

504

505

506

507

508

509

510

511

512

513
Rogers CS. 1990. Responses of coral reefs and reef organisms to sedimentation. Marine Ecology Progress Series 62:185-202.

Rose CS, Risk MJ. 1985. Increase in Cliona delitrix infestation of Montastrea cavernosa head on an organically polluted portion of the Grand Cayman. Marine Ecology 6:345-363.

Oliver TA, Palumbi SR. 2009. Distributions of stress-resistant coral symbionts match environmental patterns at local but not regional scales. Marine Ecology Progress Series 378:93-103.

Santodomingo N, Reyes J, Flórez P, Chacón-Gómez IC, van Ofwegen LP, Hoeksema BW. 2013. Diversity and distribution of azooxanthellate corals in the Colombian Caribbean. Marine Biodiversity 43:7-22.

Smithers S, Larcombe P. 2003. Late Holocene initiation and growth of nearshore turbid-zone coral reef: Paluma shoals, central Great Barrier Reef, Australia. Coral Reefs 22:499-505.

Sheppard CRC, Davy SK, Pilling GM. 2009. The Biology of Coral Reefs. Oxford: Oxford University Press.

Spalding MD, Brown BE. 2015. Warm-water coral reefs and climate change. Science 350: 769771.

Szmant AM. 2002. Nutrient enrichment on coral reefs: is it a major cause of coral reef decline? Estuaries 25:743-766.

Teece MA, Estes B, Gelsleichter E, Lirman D. 2011. Heterotrophic and autotrophic assimilation of fatty acids by two scleractinian corals, Montastraea faveolata and Porites astreoides. Limnology and Oceanography 56:1285-1296.

Valderrama D, Zea S. 2003. Esquemas de distribución de esponjas arrecifales (Porifera) del noroccidente del Golfo de Úraba, Caribe Sur, Colombia. Boletín de Investigaciones Marinas y Costeras 32:37-56.

van Oppen M, Gates RD, Blackall LL, Cantin N, Chakravarti LJ, Chan WY, Cormick C, Crean A, Damjanovic K, Epstein H, Harrison P, Jones TA, Miller M, Pears RJ, Peplow LM, Raftos DA, Schaffelke B, Stewart K, Torda G, Wanchenfeld D, Weeks A, Putnam HM. 2017. Shifting paradigms in restoration of the world's coral reefs. Global Change Biology doi:10.1111/gcb.13647.

Ward-Paige CA, Risk MJ, Sherwood OA, Jaap WC. 2005. Clionid sponge survey on the Florida Reef Tract suggest land-based nutrient inputs. Marine Pollution Bulletin 51:570-579.

Wenger AS, Harvey E, Wilson S, Rawson C, Newman SJ, Clarke D, Saunders BJ, Browne N, Travers MJ, Mcilwain JL, Erftemeijer PLA, Hobbs J-PA, Mclean D, Depczynski M, Evans RD. 2017. A critical analysis of the direct effects of dredging on fish. Fish and Fisheries 119. DOI: $10.1111 /$ faf. 12218 .

Wilkinson C. 2008. Status of coral reefs of the world: 2008. Townsville, Australia: Global Coral Reef Monitoring Network and Reef and Rainforest Research Center.

Zea S. 1987. Esponjas del Caribe colombiano. Dictyoceratida, Dendroceratida, Verongida, Haplosclerida, Poecilosclerida, Halichondrida, Axinellida, Demosphorida y Homosclerophorida. Catálogo Científico 1-286.

Zea S. 2001. Patterns of sponge (Porifera, Demospongiae) distribution in remote, oceanic reef complexes of the southwestern Caribbean. Revista de la Academia Colombiana de Ciencias 25:597-592.

Zea S, Henkel TP, Pawlik JR. 2014. The Sponge Guide: a picture guide to Caribbean sponges. Available at www.spongeguide.org (accessed March 2016). 


\section{Figure 1}

\section{Location and distribution of Varadero Reef.}

The reef continues to the South towards Barú Island.

*Note: Auto Gamma Correction was used for the image. This only affects the reviewing manuscript. See original source image if needed for review. 


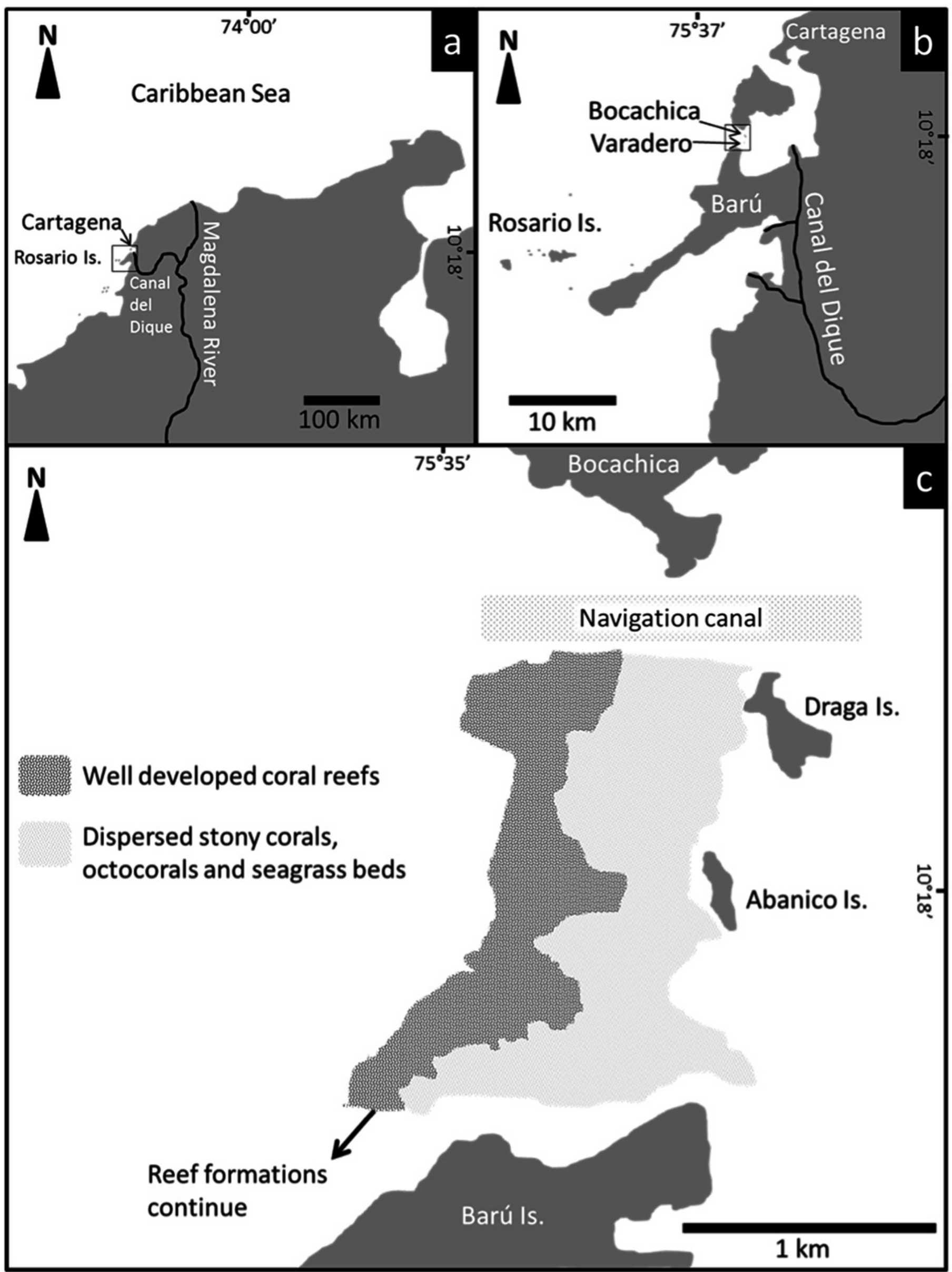


Figure 2

Varadero Reef profile

Profile of Varadero Reef showing the typical zonation and coral composition (A and B). Top panels $(A)$ correspond to each sector of the reef and the dominant scleractinian coral taxon (Credit: coauthors).

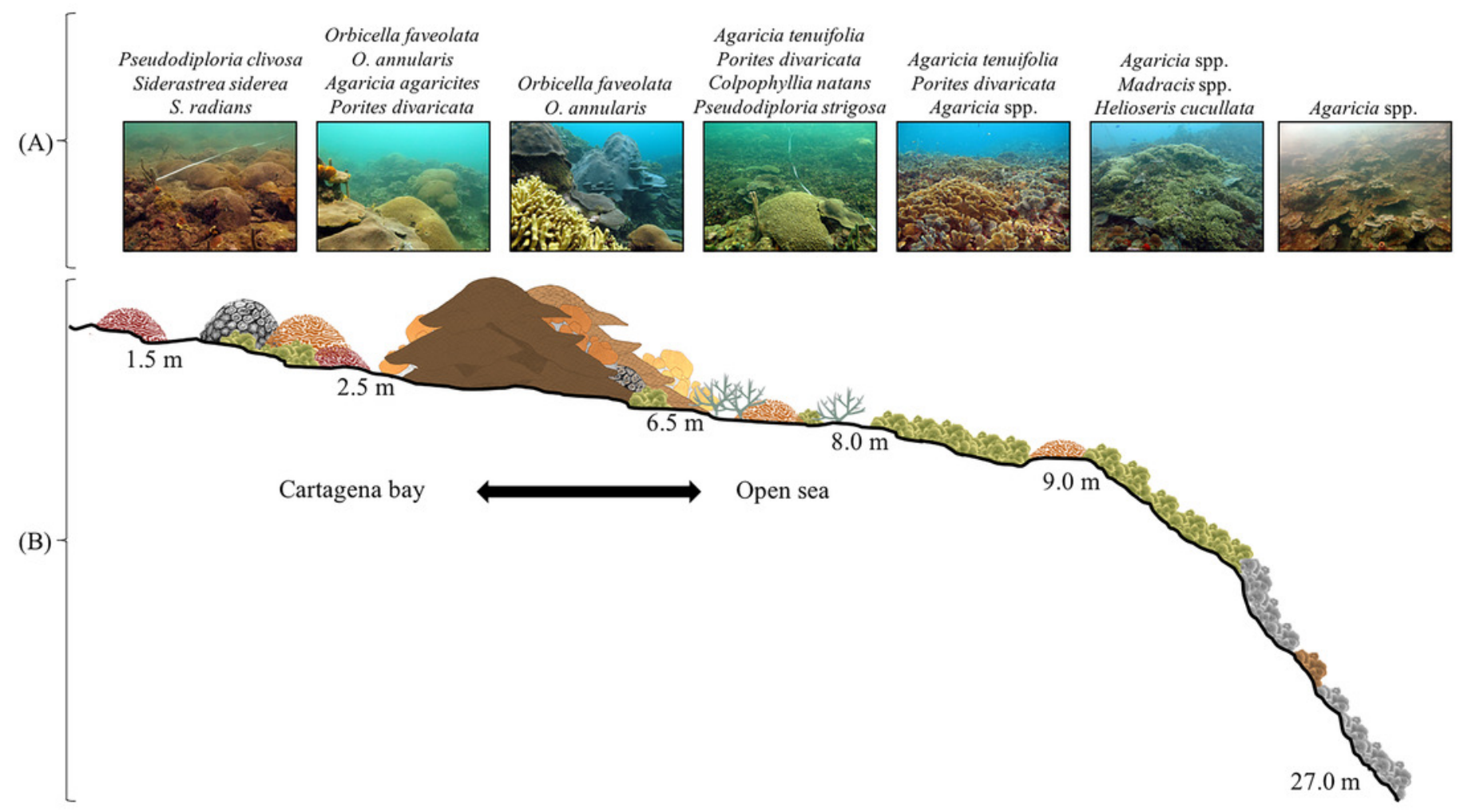




\section{Figure 3}

Varadero Reef optical properties.

Analyses of the variations in the optical properties of the water column in Varadero Reef (solid circles) indicate the presence of highly stratified water masses. The blue symbols in the blue shaded area highlight the upper layer with $K_{d}$ values of $0.488 \mathrm{~m}^{-1}$, the black symbols indicate transition region with $K_{d}$ of $0.19 \mathrm{~m}^{-1}$ whereas the orange symbols in the shaded area indicate the presence of very clear waters with $K_{d}$ values of 0.041 . For comparison the monotonic vertical attenuation for the Rosario Island is presented (open circles) with $K_{d}$ values of $0.165 \mathrm{~m}^{-1}$. 


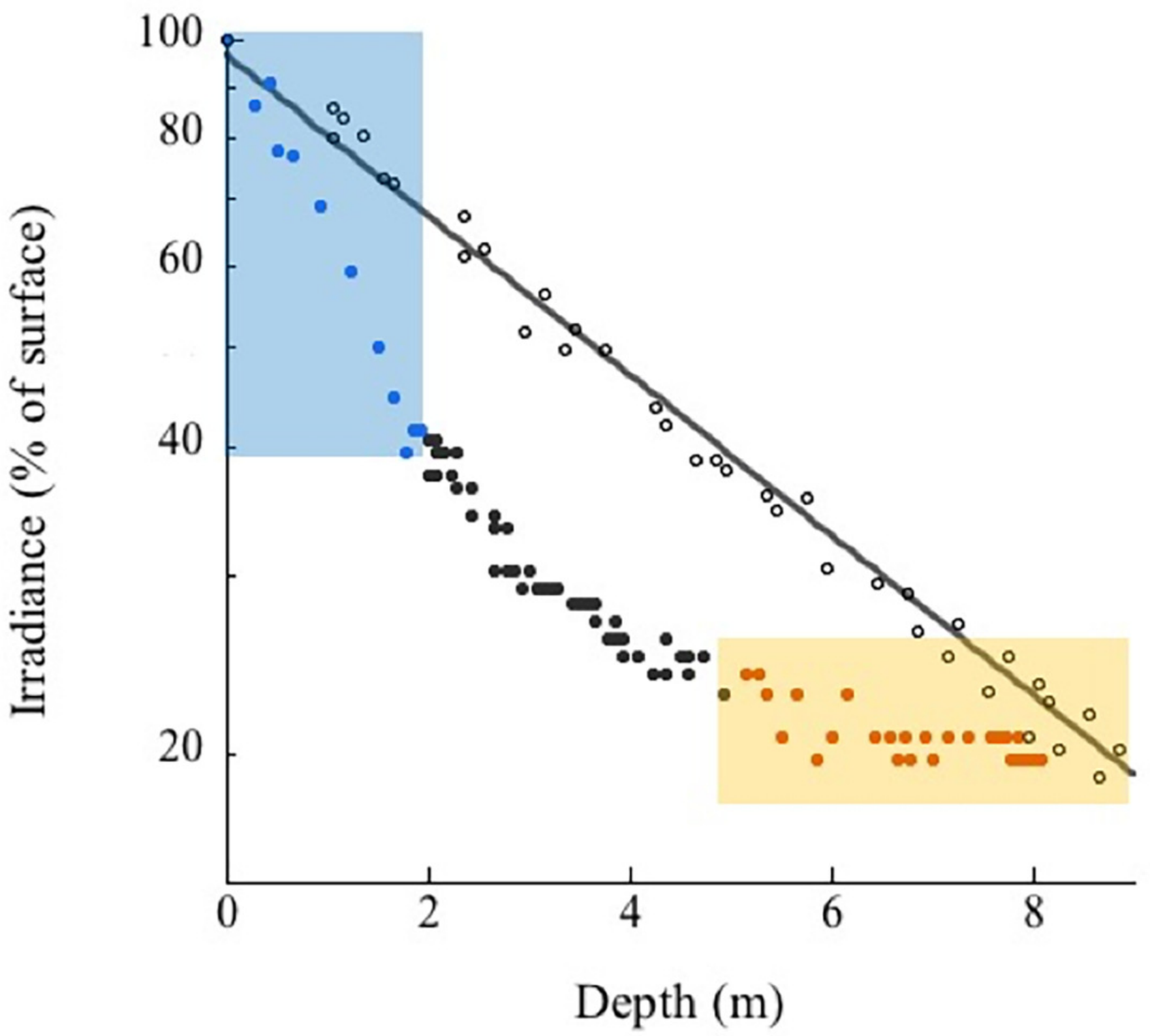




\section{Figure 4}

Varadero and Barú benthic cover.

Average benthic coverage Varadero (blue) and Barú (red) Reefs. Error bars indicate standard error.

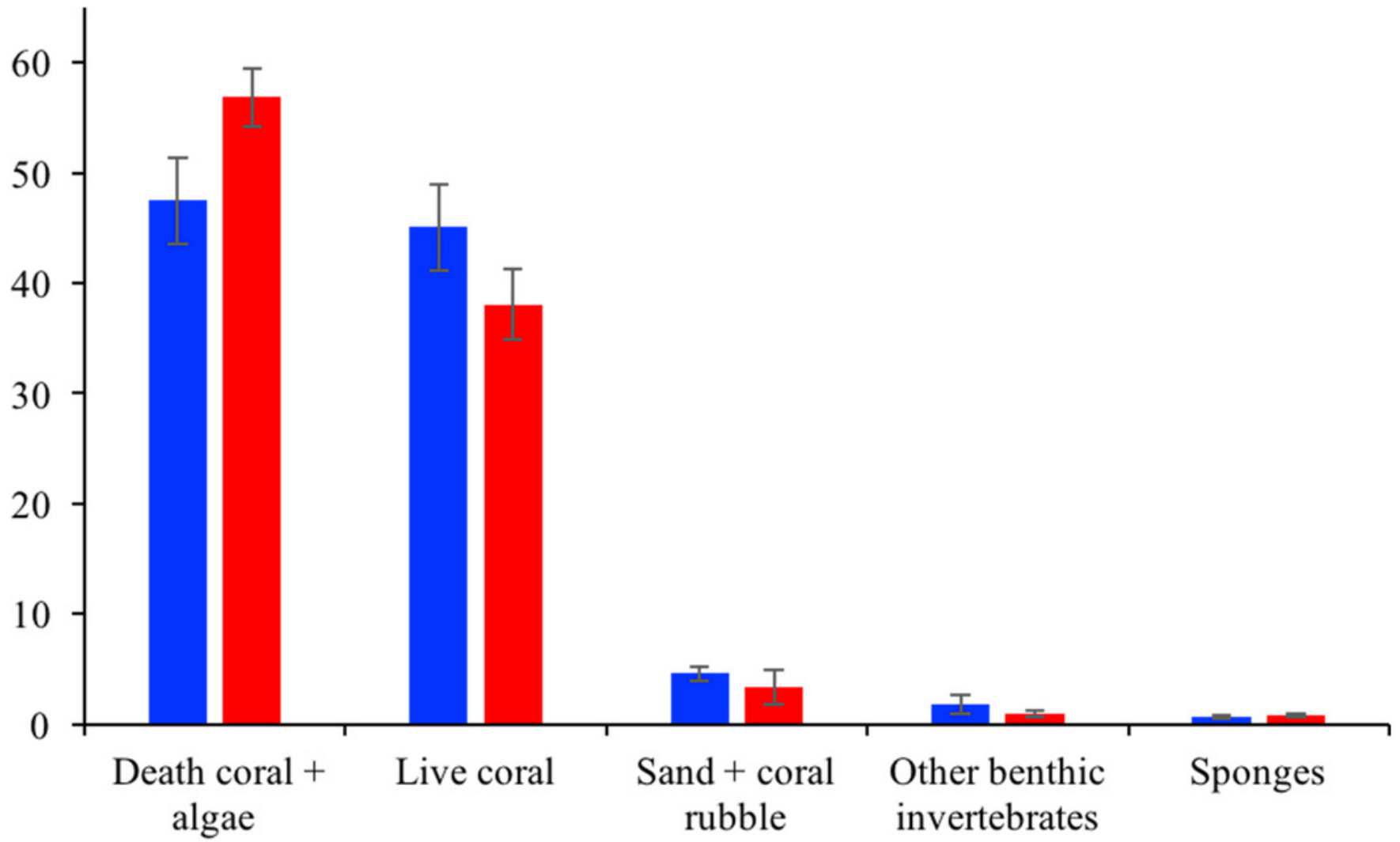




\section{Figure 5}

Fish presence-absence and abundance data for Varadero and Barú Reefs.

Non-metric multidimensional scaling analysis biplots based on A) presence-absence data (Jaccard's similarity) and B) abundance data (Bray-Curtis's similarity) for fish visual censuses made at Barú (red) and Varadero (blue) Reefs. 

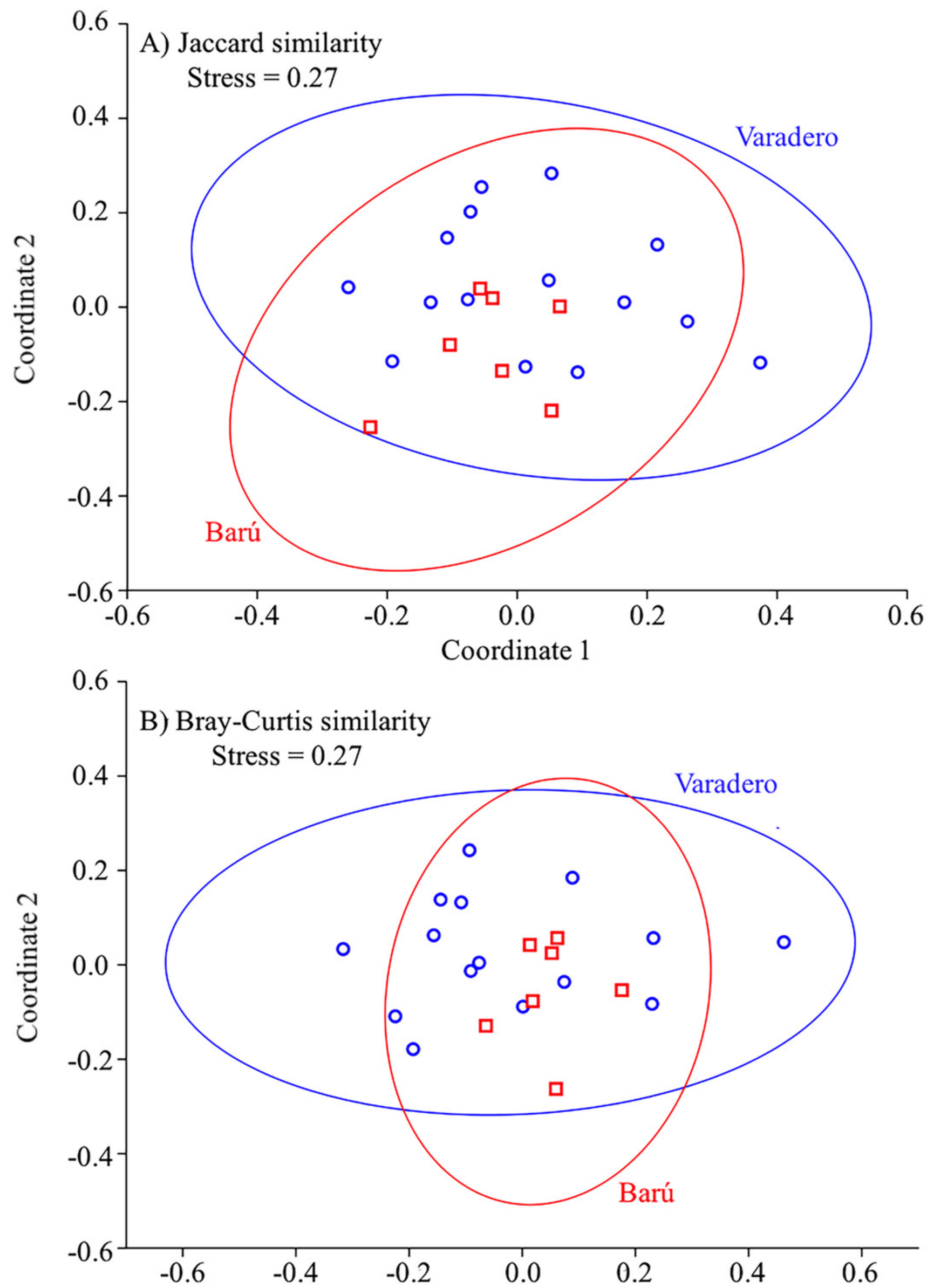

Peerj reviewing PDF | (2017:08:19657:2:0:CHECK 3 Nov (26ஞð) rdinate 1 


\section{Table $\mathbf{1}$ (on next page)}

Fish assemblage at Varadero and Barú Reefs.

Fish assemblage attributes estimated through visual censuses on $30 \times 2-\mathrm{m}^{2}$ belt transects made at Varadero and Barú Reefs. 


\begin{tabular}{|c|c|c|c|c|c|c|}
\hline \multirow{2}{*}{ Community attribute } & \multicolumn{2}{|c|}{$\operatorname{Varadero}(n=15)$} & \multicolumn{2}{|c|}{ Barú $(n=7)$} & \multirow{2}{*}{$\mathbf{t}$} & \multirow{2}{*}{$\mathbf{p}$} \\
\hline & Mean & $\pm \mathbf{S D}$ & Mean & \pm SD & & \\
\hline Species richness & 12.4 & 3.0 & 15.0 & 2.4 & -1.99 & 0,06 \\
\hline Number of individuals & 55.6 & 15.9 & 74.1 & 14.4 & -2.62 & 0,02 \\
\hline Dominance (Simpson's D) & 0.18 & 0.05 & 0.16 & 0.04 & 0.94 & 0,36 \\
\hline Diversity (Shannon's H') & 2.0 & 0.3 & 2.2 & 0.2 & -1.36 & 0,19 \\
\hline Evenness (Pielou's J') & 0.81 & 0.07 & 0.80 & 0.04 & 0.27 & 0,79 \\
\hline
\end{tabular}

1 